\title{
13 Libraries and Democracy in Germany. As Perceived by the Public in Contrast to the Professionals
}

\section{Research Questions}

This study in the context of project ALMPUB "Archives, Libraries, Museums as Public Sphere Institutions in the Digital Age" takes as its starting point the fundamental criticism voiced by Paul Jaeger and others (2013), namely that discussions on the relationship between libraries and democracy lack empirical evidence.

This takes into account the Nordic approach that considers the three key institutions of knowledge - libraries, archives and museums - together. Project partner Håkon Larsen provides an overall conceptual explanation of why these three institutions are comparable as public spaces and arenas of political discourse (Larson 2018).

The current research landscape has been explained in a report published in the Journal of Documentation and the results of representative population surveys in six countries are given in another recent article in the same journal (Audunson et al. 2019a, 2019b). The initial analyses of the survey of occupational fields were presented at CoLIS 10 (the conference "Conceptions of Library and Information Science" taking place every three years) in Slovenia in June 2019 (Audunson, Hobohm, Tóth 2019, see also Audunson, Hobohm and Tóth, this volume).

The starting point of the European project with partners from more than six countries was to establish the extent to which national populations attribute different roles to libraries in comparison to other countries, but also in comparison to the self-perceptions of library professionals in each respective country. The project is explained in more depth in the present volume. The starting points are similar projects by Ragnar Audunson and his team who for over two decades have dedicated themselves to understanding the role of the public library as a place in society (cf. e.g. Audunson 2005). The European network "Libraries in Urban Space" can be traced back to an interdisciplinary conference in Potsdam in 2012 with the title "The City of Flows - Interdisciplinary Perspectives on the Digital City in Analogue Spaces”. 
The basic research questions for the present chapter were as follows:

- How is digitalisation changing the role of libraries, archives and museums as infrastructure institutions which support open and enlightened discourse within society?

- Is there a difference between the professional self-perception and the public image of the library regarding the new roles?

It takes the German library field as the focus of investigation.

\section{Survey Methodology}

In 2017, an English-language master questionnaire was designed for a population survey, with versions for each country being prepared and translated by the project partners: Norway, Sweden, Denmark, Hungary, Germany and Switzerland. The questionnaire comprised around 30 questions which were partially designed in accordance with the European Social Survey ${ }^{1}$ (ESS) scales and tested in different environments. The survey itself was conducted in the six countries by the Norwegian social and market research company Sentio Research. Contact to the sample was achieved by means of existing panels and thus partly by self-recruitment. However, a check based on socio-demographic control variables (age cohorts, education level) showed that the sample surveyed achieved an acceptable level of representativeness of $\mathrm{N}=6050$ in all countries.

Taking the population questionnaire as a template, further 36-question English-language master questionnaires seeking to compare the role of perception and self-awareness of staff and management in the three institutions (i.e. archives, libraries and museums in each country) were developed for all three occupational fields and translated into the respective national languages with slight adjustments depending on the country and occupational field. In some cases, it was not possible to transfer the wording of individual questions and response scales directly from the population questionnaire and adapt it to match the target group. This time project partners initiated their own data collection. In Germany, the three institution surveys were conducted in summer 2018 (libraries) and spring 2019 (archives and museums). Contact to the sample was achieved via professional nationwide mailing lists or using the snowball method (self-recruitment). The librarian occupational field survey in Germany described

1 European Social Survey - European Research Infrastructure Consortium ESS-ERIC: https:// www.europeansocialsurvey.org. 
here was administered by Limesurvey Professional ${ }^{2}$ at the Potsdam University of Applied Sciences and resulted in a response rate of $N=1014$. A number of questions were optional, meaning that the full sample size was not always achieved. Even if the survey procedure did not result in a representative sample in a strict statistical sense, the socio-demographic variables surveyed (type of librarian training, catchment area of one's own library, extent of management responsibility in one's own range of tasks etc.) show a wide dispersion and no conspicuous bias.

\section{Results}

\section{Library Visits: Comparisons Within Europe}

The indicator "Market penetration" - i.e. number of library visits undertaken by a population - obviously represents an important question in comparisons between European countries. Responses to the question "How often did you physically visit a public library, a museum or an archive in the last year?" were largely in line with expectations, but nevertheless revealed a usage rate of approx. 50\% for Germany and Switzerland, which is fairly high compared to other German studies $^{3}$ (see Table 13.1, Figure 13.1). This might be an effect of the sampling method of the Sentio panel in German-speaking countries or even a bias triggered by the political climate at the time of the survey. This figure is interesting in light of the widely perceived leadership of Nordic countries: at the very least the library usage

Tab. 13.1: Library visits in the last 12 months (ALMPUB: V23, $N=6050$ ) in per cent, rounded

\begin{tabular}{llllllll}
\hline & Denmark & Sweden & Norway & Germany & Switzerland & Hungary & Total \\
\hline Never & 29 & 30 & 36 & 52 & 53 & 32 & 38 \\
$1-3$ times & 32 & 35 & 30 & 25 & 26 & 40 & 31 \\
$4-9$ times & 18 & 17 & 17 & 12 & 10 & 14 & 15 \\
$10-20$ times & 11 & 10 & 10 & 6 & 8 & 9 & 9 \\
$20+$ & 11 & 8 & 7 & 5 & 4 & 5 & 7 \\
\hline
\end{tabular}

2 https://fh-potsdam.limequery.org.

3 E.g. the representative survey commissioned by DBV and Stiftung Lesen in 2012 ("Ursachen und Gründe für die Nichtnutzung von Bibliotheken in Deutschland" = "Causes and reasons for the non-use of libraries in Germany") shows that the use of libraries (all types) "in the last 12 months" was 37\% (public libraries alone = 29\%) (see http://www.stiftunglesen.de/ bibliothekstudie). 


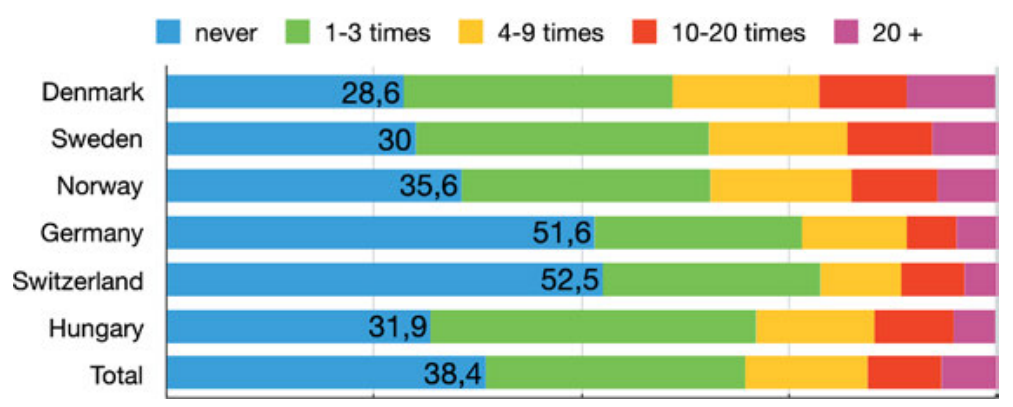

Fig. 13.1: Library visits in the last 12 months in six countries (2017) in per cent

in Germany is not as bad as often suggested, and might ultimately be at the level of other countries (any statistical artefact omitted). This difference in observed usage of libraries seems not to have an effect on the following parts of the survey because most of the following questions were overall attributions on a fixed scale which can be estimated by users as well as non-users.

\section{Social Significance of Libraries}

In order to determine the general social value attributed to LAM institutions in the countries surveyed the following item was presented in the questionnaire:

To what extent do you think libraries, archives and museums contribute in realising the following social values? Use the scale from 0 to 10, where 0 indicates not at all and 10 indicates very good. Please enter your answer in each row/column.

As far as libraries are concerned, the results tend to be relatively similar across Europe. On average, the promotion of "solidarity and a sense of community" and "democracy" is the function least ascribed to libraries (see Table 13.2, Figure 13.2). On the scale from 1 to 10, however, responses still reach national averages of 7 to max. 7.5. The highest scores in this respect are achieved by the responses of the Norwegian and German populations on the subject of "democracy", with values of 7.56 and 7.53 respectively. Germany's score of 8.34 also leads for the function ranked next in terms of importance, namely that libraries should promote "social value", "a liveable community". These statistical differences may be relatively minor, but it is interesting to note that the function least ascribed to libraries by German respondents (compared with other European countries) was the promotion 
of "knowledge and interest in history". One might have thought that the German sensitivity to history would be much higher - but perhaps this is not attributed to the library as a democratic institution. The promotion of lifelong learning, knowledge acquisition and access to culture is most likely to be ascribed to libraries by all respondents, although precisely these more traditional functions seem to predominate, particularly in Germany (i.e. they are usually higher than the Nordic countries for examples).

Tab. 13.2: To what extent do you think libraries contribute to promoting the following social values? (ALMPUB Q19A, N = 3729, response options from 0 to 10, mean values on an 11-figure scale)

\begin{tabular}{|c|c|c|c|c|c|c|}
\hline & Denmark & Sweden & Norway & Germany & Switzerland & Hungary \\
\hline $\begin{array}{l}\text { Interest in literature } \\
\text { and culture }\end{array}$ & 7.7 & 7.86 & 8.24 & 8.08 & 8.17 & 8.6 \\
\hline Lifelong learning & 7.85 & 8.04 & 8.21 & 8.24 & 8.37 & 8.62 \\
\hline $\begin{array}{l}\text { Knowledge/interest in } \\
\text { society around us }\end{array}$ & 7.8 & 7.8 & 8.13 & 8.02 & 7.94 & 8.18 \\
\hline $\begin{array}{l}\text { Solidarity and commu- } \\
\text { nity }\end{array}$ & 6.94 & 7.07 & 7.49 & 7.18 & 7.07 & 7.43 \\
\hline $\begin{array}{l}\text { Equal access to infor- } \\
\text { mation and knowledge }\end{array}$ & 8.17 & 8.14 & 8.66 & 8.48 & 8.46 & 8.64 \\
\hline $\begin{array}{l}\text { Equal access to cul- } \\
\text { tural experiences }\end{array}$ & 7.62 & 7.79 & 8.21 & 8.03 & 8.08 & 8.52 \\
\hline Democracy & 7.22 & 7.27 & 7.56 & 7.53 & 7.08 & 7.15 \\
\hline $\begin{array}{l}\text { Knowledge of other } \\
\text { cultures }\end{array}$ & 7.66 & 7.57 & 7.94 & 8.19 & 8.24 & 8.44 \\
\hline $\begin{array}{l}\text { Knowledge of and } \\
\text { interest in history }\end{array}$ & 8.05 & 8.08 & 8.36 & 7.65 & 7.8 & 8.74 \\
\hline A liveable community & 7.54 & 7.52 & 8.02 & 8.34 & 7.67 & 7.58 \\
\hline
\end{tabular}

Figure 13.2 shows the striking similarities between the six countries but also reveals some interesting country characteristics, especially in the dimensions of "democracy" and "liveable community". Any cultural explanation will be left to the reader and cannot be expanded upon here further. For the sake of clarity, the following analysis will focus on the German scores compared to the combined values of the five remaining countries. 


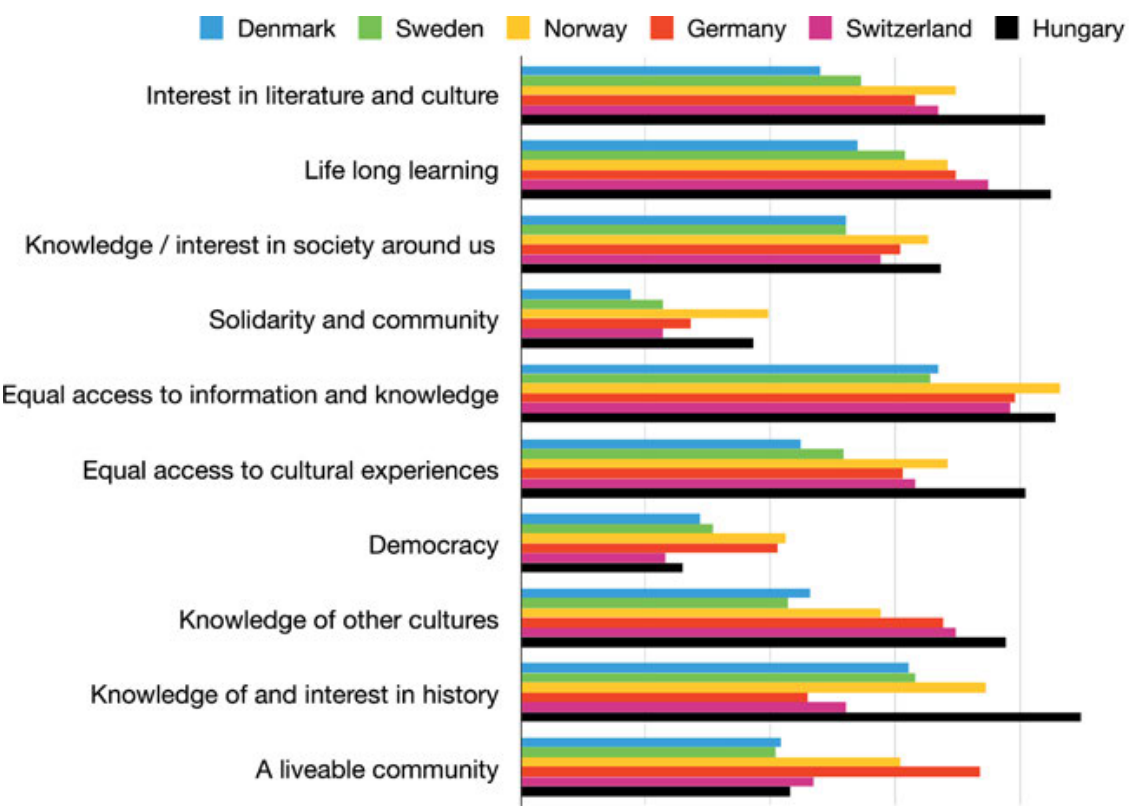

Fig. 13.2: Libraries and social values in six countries

\section{Functions of Public Libraries in Society}

Panel participants were asked specifically about the roles of libraries with the following stimulus:

A public library has many roles and there can be many reasons for upholding a public library service. A number of different reasons are given below. Could you for each of these indicate the importance on a scale from 0 to 10 as a reason for upholding a library service in your community, where 0 indicates very little important and 10 indicates of very high importance.

Here, "traditional" functions primarily promoting culture and support knowledge acquisition were also rated higher in Germany (see Table 13.3 and Figure 13.3). The values are above the country average, particularly for these aspects perceived as "traditional" by the population. Cultural heritage (item "J"), meaningful leisure activities ("K") and knowledge and everyday information ("A", "B") are given comparatively high priority for German libraries. "Democratic public discourse" (“C”) and "library as a meeting place" ("D") are also rated positively in line with the research hypothesis of the project - especially compared with other countries. It is noticeable that all aspects involving creativity, innovation ("H", "I") and "active 
involvement" (as well as "informal learning" "E"4) have lower values in Germany. The German population does not yet - at least according to this survey from 2017 perceive the library as a creative place. In terms of social integration, the role of the library as a "meeting place transcending ethnic and cultural origins" ("L") is also underestimated comparatively.

\section{Germany \\ 5 other countries \\ German librarians}

A) Information ... everyday lives

B) promotes democracy ... access to knowledge

C) promotes democracy ... public discourse

D) social meeting place

E) promotes learning

F) equal access to knowledge

G) digital devides

H) creativity and innovation ... joint activities

I) cultural expressions

J) cultural heritage

K) meaningful leisure activities

L) Integration and social cohesion
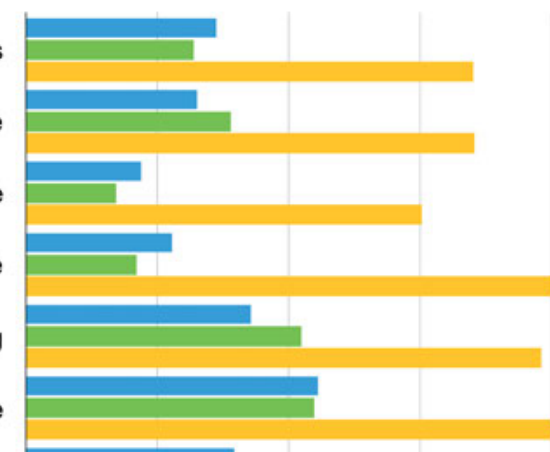

\section{$-$}

-
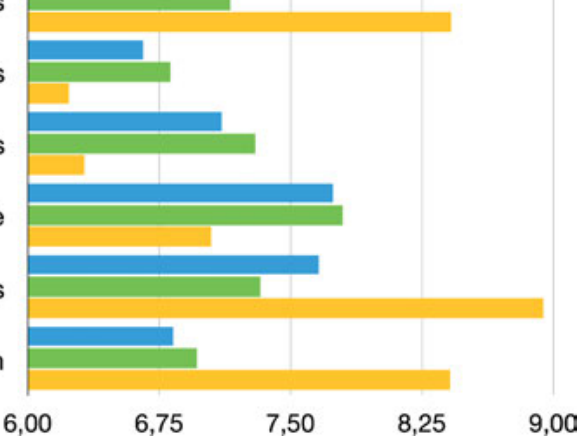

Fig. 13.3: Comparison of functions assigned to public libraries

When comparing responses from the library professionals to the same questions (third column "German librarians" in Table 13.3), it is noticeable that many social (and democratic) and information functions are rated higher by those in the profession than by the population in the representative survey. ${ }^{5}$ German library

4 This could be a problem relating to the formulation of the questions: the concept of "informal learning" may not be easy to understand.

5 See yellow bars in Figure 13.3. Note that this is a scale section with the same questionnaire scales. 
Tab. 13.3: Functions of public libraries in Germany $(N=1017$, answer options from 0 to 10 , mean values on a 11-figure scale) compared to Denmark, Sweden, Norway, Switzerland and Hungary $(\mathrm{N}=5033)$ and compared to the occupational field survey librarians $(\mathrm{N}=595)$.

\begin{tabular}{|c|c|c|c|}
\hline & Germany & $\begin{array}{l}5 \text { other } \\
\text { countries }\end{array}$ & $\begin{array}{l}\text { German } \\
\text { librarians }\end{array}$ \\
\hline $\begin{array}{l}\text { A) The library provides people with information } \\
\text { they need in their everyday lives. }\end{array}$ & 7.09 & 6.96 & 8.55 \\
\hline $\begin{array}{l}\text { B) The library promotes democracy by giving } \\
\text { citizens access to knowledge and information } \\
\text { they need to be active in their communities. }\end{array}$ & 6.98 & 7.17 & 8.56 \\
\hline $\begin{array}{l}\text { C) The library promotes democracy by being an } \\
\text { arena for public discourse. }\end{array}$ & 6.66 & 6.52 & 8.26 \\
\hline $\begin{array}{l}\text { D) The library is an important social meeting } \\
\text { place in the community. }\end{array}$ & 6.84 & 6.63 & 9.01 \\
\hline $\begin{array}{l}\text { E) The library promotes learning, supporting } \\
\text { informal as well as formal learning. }\end{array}$ & 7.29 & 7.57 & 8.94 \\
\hline $\begin{array}{l}\text { F) The library promotes equality by giving equal } \\
\text { access to knowledge resources and literary and } \\
\text { cultural experiences. }\end{array}$ & 7.67 & 7.65 & 9.09 \\
\hline $\begin{array}{l}\text { G) The library promotes equality by evening out } \\
\text { digital divides. }\end{array}$ & 7.19 & 7.16 & 8.42 \\
\hline $\begin{array}{l}\text { H) The library promotes creativity and innovation } \\
\text { by stimulating their users' spaces, opening up } \\
\text { for individual or joint activities (maker spaces). }\end{array}$ & 6.66 & 6.82 & 6.24 \\
\hline $\begin{array}{l}\text { I) The library promotes contemporary literary and } \\
\text { cultural expressions of high quality. }\end{array}$ & 7.11 & 7.30 & 6.33 \\
\hline $\begin{array}{l}\text { J) The library promotes the literary and cultural } \\
\text { heritage. }\end{array}$ & 7.74 & 7.80 & 7.05 \\
\hline $\begin{array}{l}\text { K) The library provides their users with experi- } \\
\text { ences and meaningful leisure activities, e.g. by } \\
\text { providing entertainment and popular reading } \\
\text { material. }\end{array}$ & 7.66 & 7.33 & 8.94 \\
\hline $\begin{array}{l}\text { L) The library promotes integration and social } \\
\text { cohesion by being a meeting place transcending } \\
\text { ethnic and cultural origins. }\end{array}$ & 6.83 & 6.97 & 8.41 \\
\hline
\end{tabular}


professionals are comparatively pessimistic with regard to aspects of high culture and cultural heritage ("I", "J") - this is very likely due to the focus on public libraries. The aspect "creativity and innovation ... makerspace" ("H") is rated even lower by professionals working in the institution than by the general population.

Despite the concept being repeatedly enshrined in law, the perception of the dimension "The library promotes democracy because it is a place for forming public opinion" is still comparatively underdeveloped in all countries surveyed. More widespread is the perception of the aspect of freedom of opinion and equal access to knowledge and information. In Germany, it can be noted that despite the predominance of traditional perceptions, sensitivity for these "new" roles of libraries is already quite pronounced, especially in comparison with the Nordic countries assumed to be pioneering these new approaches.

\section{Public Library as a Promoter of Democracy?}

In order to assess possibilities for promoting the postulated democratic roles of libraries, the same question was asked in the population survey and institution survey in all participating countries:

Public libraries should be institutions that promote the free formation of opinion and thus democracy. The library can perform this role in several ways and below we have specified some. How do you think your local library should prioritise these? Use the scale from 0 to 10 , where 0 indicates very low priority and 10 very high priority in relation to the goal of promoting democracy and the free formation of opinion.

Here too, the information function of libraries continues to prevail in all countries - and with particular emphasis in Germany. "Well-founded decisions" ("A") and "rights and obligations" ("B") are certainly the questionnaire-specific triggers that produce the high values in this context (see Table 13.4 and Figure 13.4). It remains difficult for all country populations to perceive libraries as an arena for public discourse, even though responses in Germany indicate they are already perceived as event venues ("D"), which in this survey were associated with the promotion of democracy due to the formulation of the question. Library professionals follow this assessment but also attach particular importance to civic skills ("F"). In particular, digital media literacy ("G") is seen here as an instrument that promotes democracy. However, the offer of libraries' own digital platforms ("E”) for the debate of municipal topics tends to be rejected in practice. 
Tab. 13.4: Priorities of options for democracy promotion by libraries (population survey $\mathrm{N}=1017$, response options from 0 to 10 , mean values of the 11-figure scale) compared to Denmark, Sweden, Norway, Switzerland and Hungary $(\mathrm{N}=5033)$ and compared to the German library occupational survey $(\mathrm{N}=594)$

\begin{tabular}{|c|c|c|c|}
\hline & Germany & $\begin{array}{l}5 \text { other } \\
\text { countries }\end{array}$ & $\begin{array}{l}\text { German } \\
\text { librarians }\end{array}$ \\
\hline $\begin{array}{l}\text { A) Provide knowledge and information which the } \\
\text { citizens need to make informed choices. }\end{array}$ & 7.78 & 7.37 & 8.99 \\
\hline $\begin{array}{l}\text { B) Provide information which the citizens need to } \\
\text { know about their rights and obligations as citizens. }\end{array}$ & 7.79 & 7.28 & 8.39 \\
\hline $\begin{array}{l}\text { C) Provide information helping citizens to keep gen- } \\
\text { erally updated and informed on community issues. }\end{array}$ & 7.32 & 7.22 & 7.89 \\
\hline $\begin{array}{l}\text { D) Be an arena for public meetings and discussions, } \\
\text { i.e. physical meetings. }\end{array}$ & 6.82 & 6.65 & 7.37 \\
\hline $\begin{array}{l}\text { E) Provide digital arenas for discussing community } \\
\text { issues. }\end{array}$ & 6.48 & 6.55 & 5.66 \\
\hline F) Develop civic skills related to traditional media. & 6.74 & 6.74 & 7.82 \\
\hline G) Develop civic skills related to digital media. & 6.64 & 6.68 & 8.03 \\
\hline
\end{tabular}

Germany 5 other countries German librarians

A) Information ... informed decisions

B) Information ... rights and obligations

C) informed on community issues

D) arena for physical meetings

E) digital arena

F) skills for traditional media

G) skills for digital media
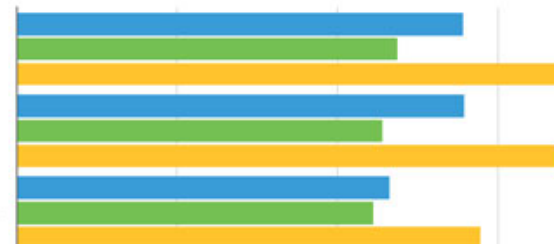

\section{$\sqrt{-1}$}




\section{Roles and Competences of Librarians}

In addition to a number of other questions, the librarians surveyed were finally asked whether they ascribe to themselves a role in promoting democracy, or whether they feel the competences required are lacking in their specific context. The question was as follows:

The role as a library professional is a complex one. How similar do you perceive your role as a library professional in the community you work are to the roles listed below. Place yourself on a scale from 0 to 5 , where 0 means that the role is not similar to the roles you play at all and 5 means very similar. The library role is similar to the role of a...

The different roles mentioned above represent different competences. Are there any of the competences listed in the roles that you feel your library is missing in order to fulfil its role in the community? Mark up to five roles which you feel represent competences lacking in your library/ which cannot be fulfilled.

The result is an interesting ranking of the roles assigned to those working in libraries (see Figure 13.5). After the classic job descriptions such as "information, knowledge and literature mediator", the relevant roles of an "agent for enlightenment and education" and an "agent for freedom of expression and information" follow very closely, also closely followed by "facilitators", "teachers" and "event managers”. In the first areas, competence deficits in respondents' own libraries were relatively seldom identified. Deficits were identified in the pedagogicalpsychological field but also in the field of social and youth work and especially in the role as "integration consultant" and as "community developer" (in the entries to the open question "Other", several respondents noted that the roles "change manager" and "media pedagogue" were missing from the questionnaire). Finally, it comes as no surprise that gaps in competence were also identified in IT, social media and web design.

Above all this means that librarians, in addition to their traditional role as information and knowledge mediators, actually do perceive themselves as guarantors of freedom of opinion, education and training for the public sphere as defined by Habermas (1989, see introduction of the present volume), and also ascribe these competences to themselves. This is to say that they - at least in Germany do accept their role in democracy and are able to fulfil it. 


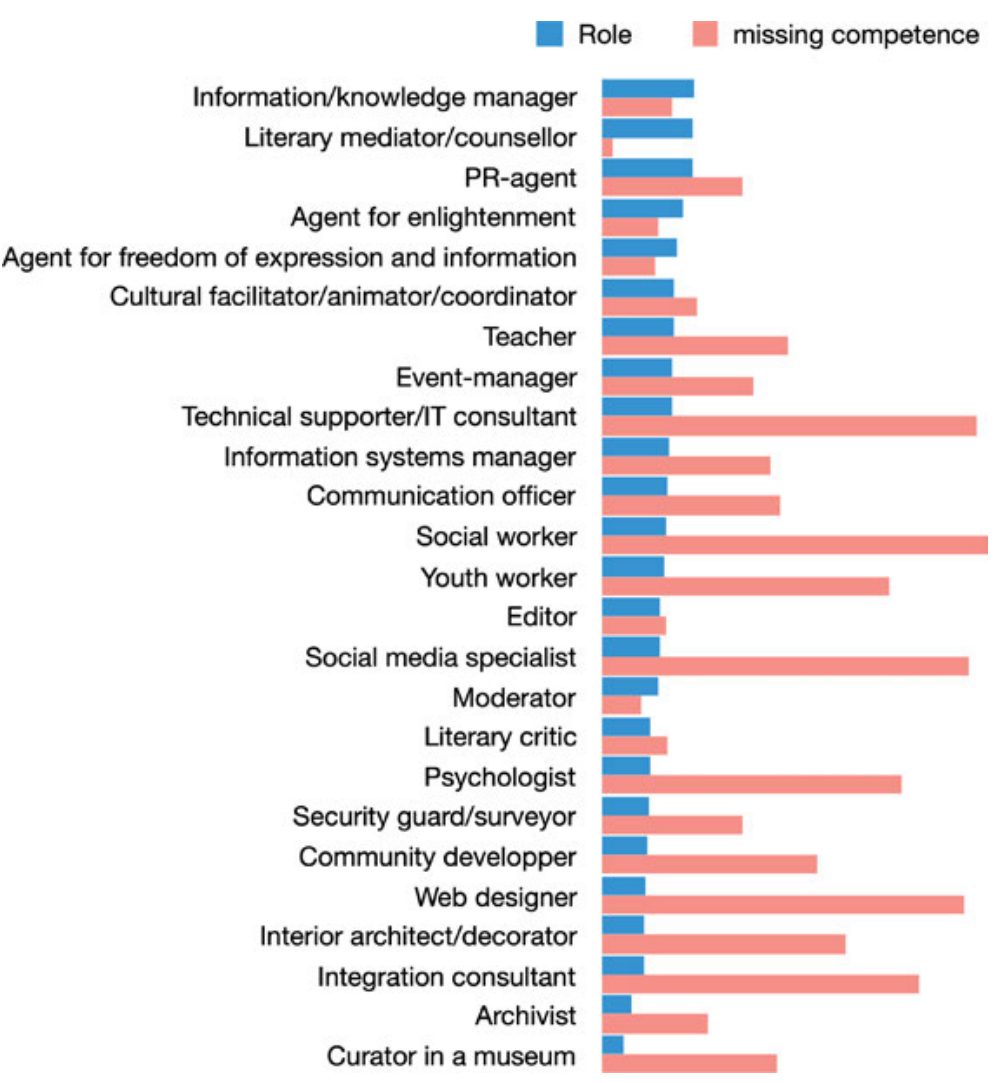

Fig. 13.5: Role self-attributions and perceived competence deficits - German library field survey, $\mathrm{N}=579$, scale of $0-5$ (V14), or multiple answers, max. 5 (V15)

\section{Conclusion}

Overall, it is clear that libraries (and here the public libraries as pioneers) exhibit the kind of social responsiveness postulated by Widdersheim (2018). In an intraEuropean comparison, different social and infrastructural conditions can be seen to result in differences in use and the attribution of functions. For example, the digital use of libraries is clearly lower in countries with less developed digital infrastructures (such as Hungary). Many of the variables observed in the ALMPUB network surveys can be linked to cultural and structural differences. However, the fact that the library and cultural laws of Nordic countries draw more profound and explicitly links between libraries and democracy does not have as strong an effect as might be expected. A number of more in-depth analyses of the avail- 
able data are still pending. Initial inferential evaluations of the statistics suggest that the factor "trust in social institutions" is significant (Audunson et al. 2019b), which may be an important aspect of the relation to modern political theory as discussed in the introductory chapter (Audunson et al., this volume). Following elaborate quantitative surveying, further analyses of the collected data material must now follow and, if necessary, qualitative methods must be used to identify further consequences and requisite conditions for librarian initiatives undertaken for the benefit of democratic society.

While the data obtained so far should be treated with caution, a positive tendency can be observed throughout Europe, but especially in Germany: on the one hand there is (some) support among the population for the political function of libraries, and on the other library professionals themselves view this role quite positively in principle. Perhaps it would help to go on the offensive here, and also to participate actively in discourse around the role and form of democracy in our time. Should rationalism's orientation towards a neutral consensus in which libraries "only" contribute to the generation of knowledge for rational discourse suffice? Or does an "arena” or "agora” not imply much more debate, involvement and dialogue face to face - as French political theorists suggest (Huzar 2013, see introductory chapter)? Perhaps - in the spirit of David Lankes' (2011) dictum that knowledge only comes from conversation - we should initiate talk. And in times of disruptive renewal, democracy needs a lot of knowledge and conversation.

Acknowledgment: Translated by Steve Mortimer, Berlin. A first version of parts this chapter has been presented at the German National Library Congress, march 2019 in Leipzig (cf. Hobohm 2019).

\section{References}

Audunson, R. “The Public Library as a Meeting-place in a Multicultural and Digital Context”. Journal of Documentation, 61, no. 3, 429-441, 2005.

Audunson, R., S. Aabø, R. Blomgren, et al. "Public Libraries as an Infrastructure for a Sustainable Public Sphere”. Journal of Documentation, 75, no. 4, 773-790, 2019.

Audunson, R., S. Aabø, R. Blomgren, H.-C. Hobohm, et al. "Public Libraries as Public Sphere Institutions. A Comparative Study of Perceptions of the Public Library's Role in Six European Countries". Journal of Documentation, 75, no. 6, 1396-1415, 2019. doi:10.1108/JD-022019-0015.

Audunson, R., H.-C. Hobohm, and M. Tóth. “ALM in the Public Sphere. How do Archivists, Librarians and Museum Professionals Conceive the Respective Roles of their Institutions in the Public Sphere?”. Information Research, 24, no. 4, 2019. papercolis1917.

Audunson, R., H.-C. Hobohm, and M. Tóth. "ALM Professionals and the Public Sphere: How do Librarians, Archivists and Museum Professionals Conceive the Respective Roles of their 
Institutions in the Public Sphere?". In Audunson, R., H. Andresen, C. Fagerlid, E. Henningsen, H-C. Hobohm, H. Jochumsen, H. Larsen, and T. Vold (eds), Libraries, Archives and Museums as Democratic Spaces in a Digital Age. Berlin: De Gruyter Saur, 2020.

Audunson, R., H. Andresen, C. Fagerlid, et al. "Introduction - Physical Places and Virtual Spaces: Libraries, Archives and Museums in a Digital Age”. In Audunson, R., H. Andresen, C. Fagerlid, E. Henningsen, H-C. Hobohm, H. Jochumsen, H. Larsen, and T. Vold (eds), Libraries, Archives and Museums as Democratic Spaces in a Digital Age. Berlin: De Gruyter Saur, 2020.

Habermas, J. The Structural Transformation of the Public Sphere: An Inquiry into a Category of Bourgeois Society. Cambridge: Polity Press, 1989.

Hobohm, H.-C. "Bibliotheken und Demokratie in Deutschland. Ergebnisse eines europäischen Projektes zu ihrer Rolle und ihrem Engagement für Demokratie und Gemeinwohl". o-bib. Das offene Bibliotheksjournal, 6, no. 4, 7-24, 2019.

Huzar, T. J. "The Public Library Democracy and Rancière's Poetics of Politics”. In Information Research 18 (Proc. of CoLIS 8), paper C15, 2013. http://InformationR.net/ir/18-3/colis/ paperC15.html.

Jaeger, P. T., U. Gorham, J. C. Bertot, et al. “Democracy, Neutrality, and Value Demonstration in the Age of Austerity”. The Library Quarterly, 83, no. 4, 368-382, 2013.

Lankes, R. D. “The Atlas of New Librarianship”. Cambridge, Mass, 2011.

Larsen, H. "Archives, Libraries and Museums in the Nordic Model of the Public Sphere”. Journal of Documentation, 74, no. 1, 187-194, 2018.

Widdersheim, M. M. “A Political Theory of Public Library Development”. Libri, 68, no. 4, 269289, 2018. 